\title{
ДІЯЛЬНІСТЬ РАДИ МОЛОДИХ УЧЕНИХ: ПРОБЛЕМИ, РИЗИКИ, ПЕРСПЕКТИВИ
}

\author{
Наукова доповідь на загальних зборах НАПН України 17 грудня 2019 р.
}

https://doi.org/10.37472/2707-305X-2019-1-1-1-9

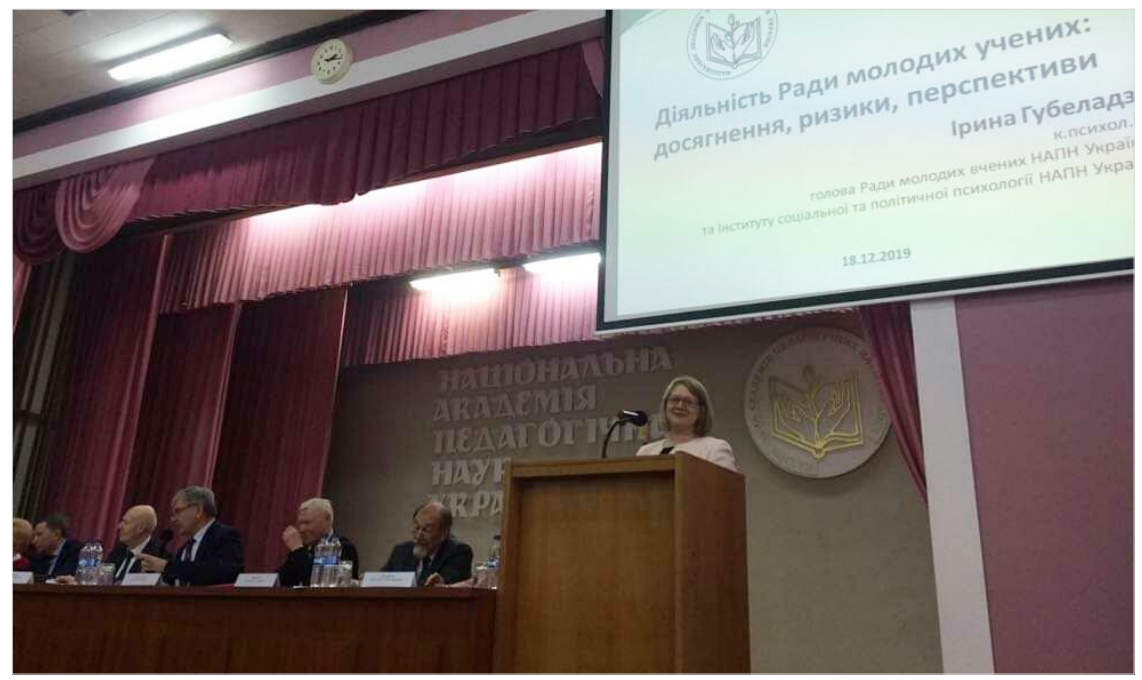

\author{
ГУБЕЛАДЗЕ \\ Ірина Гурамівна \\ кандидат психологічних \\ наук, докторант лабораторії \\ психології мас і спільнот, \\ голова Ради молодих вчених \\ Iнституту соціальної та \\ політичної психології Націона- \\ льної академії педагогічних \\ наук України, голова Ради \\ молодих вчених Начіональної \\ академії педагогічних наук \\ України, м. Київ, Україна
}

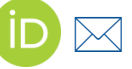

Анотація. У доповіді представлено основні напрями діяльності та здобутки Ради молодих вчених Національної академії педагогічних наук України, серед яких: захист і сприяння реалізації прав та інтересів молодих учених підвідомчих установ НАПН України, підтримка і супровід молодих учених у їхньому професійному становленні, вдосконалення іншомовної компетентності, підвищення компетентності з використання ІКТ, зокрема і платформ Web of Science, Scopus, Open Ukrainian Citation Index, проведення міндисциплінарних досліджень, презентації себе у світовому науковому просторі, відстоювання принципів академічної доброчесності, взаємодія з громадськістю, співпрачя молодих вчених всередині НАПН України та з Радами молодих вчених НАН України, МОН України, Державного науково-дослідного інституту МВС України і національних галузевих академій України. Окреслено деякі проблемні питання, а саме необхідність посилення і фінансової підтримки міжнародної діяльності молодих вчених, підтримки наукової молоді, підвищення престижності наукової діяльності серед населення, популяризації наукової діяльності серед молоді, необхідність зосередження істотної частини державного замовлення на підготовку психологічних кадрів за докторськими і магістерськими програмами у наукових установах психологічного профілю, загрозливу тенденцію до зменшення державного замовлення і зменшення фінансування підготовки докторів філософії та докторів наук.

Ключові слова: молоді науковці; Рада молодих вчених; пріоритети діяльності.

Вельмишановні учасники зборів, шановні запрошені і присутні!

Вдячна за можливість представити результати діяльності Ради молодих вчених НАПН України та висвітлити ті актуальні завдання, виклики та перспективи, які постають перед науковою молоддю НАПН України.

Рада молодих вчених Національної академії педагогічних наук України все ще знаходиться в процесі свого становлення, і у 2019 р. відбулося переобрання складу Ради та затверджено Президією НАПН України нову редакцію Положення про Раду молодих вчених НАПН
України, яке було підготовлено і укладено з урахуванням відповідних змін у чинному законодавстві України. Наразі Рада складається з 28 осіб - по два представники від кожної підвідомчої установи НАПН України, окрім Українського науково-методичного центру практичної психології і соціальної роботи, який має одного представника, та три асоційовані члени Ради.

Відповідно до Положення метою діяльності Ради $є$ представництво, захист і сприяння реалізації прав та інтересів молодих учених підвідомчих установ НАПН України. Тому заходи, організовані Радою, ініційовані самими молодими вченими і спрямовані на 
забезпечення їхніх прагнень до професійного розвитку, зокрема:

- щорічна Всеукраїнська науково-практична конференція молодих учених «НАУКОВА МОЛОДь» (Рада молодих вчених Інституту інформаційних технологій і засобів навчання НАПН України);

- круглий стіл «Наукова молодь в умовах інтеграції України в міжнародний освітній та дослідницький простір: сучасний стан, проблеми, перспективи» (Державна науково-педагогічна бібліотека України імені В.О. Сухомлинського);

- круглий стіл «Розбудова іміджу молодих вчених у сучасному інформаційному суспільстві» в рамках III Міжнародної наукової конференції «Імплементація європейських стандартів в українські освітні дослідження»;

- щомісячний англомовний семінар для науковців «Open Up!»;

- науково-практичний тренінг-марафон «OpenAir»;

- методологічні семінари з підвищення рівня обізнаності молодих вчених з використання IKT, проведення міждисциплінарних досліджень, презентації себе у світовому науковому просторі, подолання прокрастинації, коректної побудови презентації тощо;

- круглий стіл, який присвячений 71-й річниці прийняття Загальної декларації прав людини;

- «Erasmus+ JeanMonnet Programme: можливості для молодих вчених» (Ірина Сікорська);

- «Можливості програми Fulbright для українських дослідників» (Вероніка Алексанич);

- круглий стіл «Роль наукової молоді у розвитку науки України».

Одним із пріоритетів діяльності Ради $є$ налагодження тісної співпраці з молодими вченими інших установ, зокрема Радою молодих учених при Міністерстві освіти і науки України (І.Г. Губеладзе $є$ членом Ради), Радою молодих вчених Національної академії наук України, Міжгалузевою Радою молодих вчених (ради молодих вчених усіх національних галузевих академій), Радою молодих вчених Державного науково-дослідного інституту Міністерства внутрішніх справ України. Так у співпраці було проведено низку спільних заходів, внесено пропозиції до нормативної бази щодо питань наукової діяльності, зокрема і захисту прав молодих науковців.

Спільно з керівним складом рад молодих вчених національних галузевих академій було підготовлено низку листів-звернень до Уряду та Верховної Ради України щодо захисту прав науковців, у тому числі і молодих вчених, та пропозиції щодо перегляду тарифної сітки і збільшення можливостей фінансування наукової сфери загалом. На жаль, надіслані листи залишилися без відповіді і гідної уваги.

Також І.Г. Губеладзе є членом двох робочих груп Європейської ради аспірантів і молодих дослідників, а саме «Підготовка докторів філософії» та «Психологічне благополуччя молодих науковців», що дає змогу в тіс- ному контакті вивчити європейський досвід підготовки докторів філософії та ділитися українським досвідом і напрацюваннями. Враховуючи досвід європейських колег, на нашу думку, вкрай важливими є вивчення якості підготовки докторів філософії в Україні, можливості для розвитку молодих науковців, привабливість дослідницької кар'єри для талановитої молоді та працевлаштування, психічне здоров'я, баланс роботи та приватного життя, географічна, інтерсекторальна та міждисциплінарна мобільність на всіх етапах кар'єри, сприятливе дослідницьке середовище, (не)стабільність працевлаштування, фінансування та пенсійне забезпечення тощо.

Для наукової молоді НАПН України створення і діяльність Ради стало платформою для об'єднання зусиль та згуртованої співпраці на основі партнерства, а не конкуренції. Така взаємодія формує бажання не просто слідувати за лідером, а перебувати у співпраці й мати можливість самому ставати лідером. Молодий учений - це не тільки вікова категорія. Це важливий етап становлення науковця, коли виникає більше запитань, ніж відповідей. І на цьому етапі важливою $€$ підтримка більш досвідчених колег, але не з позиції авторитарності чи домінування, а з позиції партнерства, щоб спрямувати молодого вченого не лише на вдосконалення того, що вже існує, а на пошук нестандартних рішень, створення унікального продукту.

Дякуючи підтримці керівництва Національної академії педагогічних наук України, зокрема В.Г. Кременя, що була зафіксована у наказі НАПН України «Щодо підтримки діяльності молодих вчених НАПН України» від 13 травня 2019 р. № 30 о.д., у 2019 р. було започатковано і проведено у більшості підвідомчих установ НАПН України конкурс «Кращий молодий учений та аспірант». Проведення цього конкурсу ініціювала Рада молодих вчених Інституту інформаційних технологій і засобів навчання НАПН України. На основі їхнього досвіду був підготовлений проект Положення про конкурс «Кращий молодий вчений та аспірант Національної академії педагогічних наук України». Сподіваємося, що наступного року аналогічний конкурс ми зможемо провести і на рівні НАПН України.

У 2019 р. вперше за поданням Ради молодих вчених НАПН України до Дня науки було нагороджено відзнаками НАПН України сім найактивніших молодих вчених НАПН України (Л.М. Дяченко, І.Г. Губеладзе, Д.В. Васильєву, А.В. Яцишин, С.В. Тарнавську, О.В. Орлова, О.А. Чиханцову).

Водночас ми хотіли 6 зосередити увагу на актуальних питаннях молоді НАПН України.

Маємо констатувати, що міжнародна діяльність молодих вчених НАПН України наразі залишається переважно на рівні індивідуальних проектів наукової і академічної мобільності через брак фінансування та відсутність відповідних статей витрат на закордонні відрядження, публікації у міжнародних виданнях та участь у міжнародних наукових заходах. Також окрему 
увагу варто приділити збільшенню можливостей підготовки та підвищення кваліфікації українських психологів-науковців за кошти державного бюджету у провідних зарубіжних університетах, а також в Україні за участю зарубіжних викладачів.

Вже котрий рік ми спостерігаємо зниження як кількості, так і якості професійної підготовки тих, хто вступає в аспірантуру для здобуття ступеня доктора філософії. 3 огляду на це вкрай загрозливою $є$ тенденція до зменшення державного замовлення і зменшення його фінансування на підготовку докторів філософії та докторів наук за рахунок бюджетних коштів. Відтак здобувачі ступеня доктора філософії змушені шукати додаткові джерела фінансування (підробіток), що безумовно позначається на якості та успішності їхньої дослідної роботи, на задоволенні від наукової роботи. Перевтома, виснаження, незадоволення і знецінення свої діяльності спонукають велику частину молодих учених полишати наукову сферу. А відтак маємо стрімкий відтік наукової молоді і висококваліфікованих фахівців з галузі у приватний сектор або за кордон.

3 огляду на це важливим $є$ питання підтримки наукової молоді як з боку колег, так і з боку керівництва установ і НАПН України, а також підвищення престижності наукової діяльності загалом серед населення, в першу чергу через забезпечення гідної заробітної плати для висококваліфікованих фахівців інтелектуальної праці. Важливим кроком $є$ і популяризація наукової діяльності серед молоді. 3 метою підготовки висококваліфікованих кадрів для вступу в аспірантуру і здійснення наукової діяльності вважаємо необхідним зосередження істотної частини державного замовлення на підготовці психологічних кадрів за докторськими і магістерськими програмами у наукових установах психологічного профілю НАПН України.

Потребує поетапного збільшення обсяг державного замовлення на підготовку психологів за магістерськими та докторськими програмами відповідно до потреби держави у психологічних кадрах для наукової та практичної роботи.

Ще одним важливим кроком вважаємо проведення комплексного дослідження психологічного благо- получчя здобувачів ступеня доктора філософії, зокрема співвідношення їхньої мотивації вступу до аспірантури, очікування та отриманих результатів, особливості входження у наукове середовище, зокрема взаємодії з колегами і науковим керівником, задоволеності науковою діяльністю, можливістю працевлаштування тощо. Розроблення на основі отриманих результатів конкретних рекомендацій для Уряду, МОН України та установ, що здійснюють підготовку докторів філософії, з метою підвищення ефективності такої діяльності.

Крім того, з огляду на вже створену коаліцію молодих дослідників у межах НАПН України, яка активно діє і переконливо демонструє свою ефективність, актуальним на сьогодні вважаємо необхідність організаційної підтримки і забезпечення відповідного фінансування можливостей реалізації науковою молоддю спільних міждисциплінарних наукових проектів, що $€$ трендом світової науки.

Важливим $є$ заохочення молодих науковців НАПН України до участі у конкурсах на отримання іменних стипендій і премії Верховної Ради України, премії Президента України та стипендії Кабінету Міністрів України для молодих учених, інших державних і недержавних конкурсів і програм, зокрема керівником наукової роботи і адміністрацією підвідомчої установи НАПН України.

Для підвищення мотивації досягнення успіху в науковій діяльності та громадській активності молодих вчених важливим $€$ пошук можливостей для преміювання найактивніших молодих учених в межах підвідомчих установ та на рівні НАПН України.

I насамкінець хочу подякувати усім членам Ради молодих учених НАПН України і науковій молоді підвідомчих установ за Вашу активність і небайдужість до науки і нашої спільної справи. Дякую вельмишановному Василеві Григоровичу, шановним академікамсекретарям відділень, директорам підвідомчих установ і завідувачам відділів за підтримку молодих учених.

Для нас дійсно важлива Ваша підтримка!

Дякую за увагу!

\section{THE YOUNG SCIENTISTS COUNCIL ACTIVITY: PROBLEMS, THREADS, PROSPECTS Scientific report at the General Meeting of the National Academy of Educational Sciences of Ukraine, December 17, 2019}

Iryna Hubeladze

PhD in Psychology, DSc Student of the Department of Mass and Communities Psychology, Head of the Young Scientists Council, Institute for Social and Political Psychology of the National Academy of Educational Sciences of Ukraine; Head of the Young Scientists Council of the National Academy of Educational Sciences of Ukraine, Kyiv, Ukraine

Abstract. The report presents the main activities and achievements of the Young Scientists Council of the National Academy of Educational Sciences of Ukraine, including protection and promotion of the rights and interests of young scientists in the institutions of NAES of Ukraine, support of young researchers in their professional development, improvement of foreign language competence, use of ICT, including such platforms as Web of Science, Scopus, Open Ukrainian Citation Index, conducting interdisciplinary research, presenting oneself in the scientific world. It is open to advocacy of principles of academic integrity, interaction with the public, cooperation between young scientists within NAES of Ukraine and with the Young Scientists Councils of the National Academy of Sciences of Ukraine, Ministry of 
education and Science of Ukraine, State Research Institute of the Ministry of Internal Affairs of Ukraine and national sectoral academies of Ukraine. Some problematic issues are outlined, namely strengthening and financial support of young scientists' international activity, support of scientific youth, increase of prestige of scientific activity among the population, popularization of scientific activity among young people, the need to concentrate a substantial part of the state order for the training of psychological staff for doctoral and master's programs in research institutions of psychological profile, threatening tendency to decrease of the state order and funding for the training of PhDs and Doctors of Science.

Keywords: young scientists; Young Scientists Council; priorities of activity.

Дата публікації: 23 грудня 2019 р. 